\title{
INDUSTRY STRUCTURE AND ORGANIZATION STRUCTURE OF THE LOW SCALE HOTEL ORGANIZATIONS
}

\author{
Nor Khomar Ishak \\ UNITAR International University Malaysia, Selangor, Malaysia \\ Khursiah Abd Aziz \\ Kuala Lumpur Metropolitan University College, Malaysia \\ Siti Nor Amira \\ UNITAR International University Malaysia, Selangor, Malaysia
}

\begin{abstract}
Organization structure considered the anatomy of the organization, providing a foundation within which the organization functions. Organization structure is believed to affect the behavior of organization members. The purpose of this study was to examine the relationship of industry structure and organizational structure. A total of 110 hotel firms across Malaysia country that were rated as 3-star were invited for participation. The respond rate was 22 3-star hotels participate and this represented 20 percent of respond rate. Results indicated that the level of industry attractiveness of the 3-star hotel group was slightly unattractive. The 3-star hotel group organizational structure was considered as slightly closed. This study was able to determine the extent of industry attractiveness through the identification of the variables and factors contributing towards the industry attractiveness and the extent of organization structure.
\end{abstract}

Key words: Organizational structure, low scale hotel organization.

Cite this Article: Nor Khomar Ishak, Khursiah Abd Aziz and Siti Nor Amira, Industry Structure and Organization Structure of the Low Scale Hotel Organizations, International Journal of Management, 11(12), 2020, pp 457-469.

http://iaeme.com/Home/issue/IJM?Volume=11\&Issue=12

\section{INTRODUCTION}

The conditions of the external environment should form the basis for designing the hotel organizational internal processes, systems, and strategies. The dynamism of the external environment caused by the extent of global environmental turbulence had apparently influenced the internal systems and processes within the hotel through the adjustment required 
on the strategic direction and tactical methods employed. The external environment had been relatively volatile during the past 15 years and the hotel organizations had made tactical adjustments by expanding their major customer base, pricing and promotional methods as part of its competitive tactics. These were appropriate steps in view of the shift in emphasis in the overall tourism industry marketing and product development programs. Such development encompassed the increased in products' scope and breadth by non-traditional products such as the gaining popularity of the homestays and the budget hotels and the emergence of the Airbnb market which had greatly affected the 3-star hotel organizations.

\subsection{The Purpose of the Study}

The purpose of the study were to examine the factors comprising the low scale hotel industry structure, to investigate the low scale hotel organization level of industry attractiveness, to find out the factors that determined organizational structure, determine the low scale hotel organizations structure inclination, and to determine the extent of association between the low scale hotel organizations level of industry attractiveness and the organizational structure.

It is proposed that the low scale hotel organizations structural orientation would be related to the hotel industry level of attractiveness:

- When the hotel industry is attractive, the low scale hotel organizations would adopt an open organizational structure.

- When the hotel industry is unattractive, the low scale hotel organizations would adopt a closed organizational structure.

\section{LITERATURE OVERVIEW}

Porter (1980) indicated that the essence of formulating competitive strategy is relating the firm to its environment, and the key aspect of the firm's environment is the industry in which it competes. An industry is defined as a group of firms producing products/services that are close substitutes for each other. The collective strength of the five forces determined the ultimate profit potential of the industry and the size of the market share. Porter further identified the state of competitiveness in an industry as composed of five basic competitive forces: (1) Threat of new entrants, because new entrants will bring added capacity and the desire to gain market share; (2) Bargaining power of buyers, for if they are large they will have the ability to exert control over price, and the threat of backward integration; (3) Bargaining power of suppliers, who can exert pressure on price and control quality which can thus reduce profitability of the industry as a whole; (4) Pressure from substitute products/services which can limit the profit potential of the industry by setting a ceiling on price, and (5) Intensity of rivalry among the existing competitors which can exert pressure on price. Another factor, the level of government support, should also be given due consideration. This factor is important since the development and attractiveness of the local industry depends, to some extent, on the government's active role and support, especially in the developing countries. The combination of these factors will determine the level of industry's attractiveness.

According to Schaffer (1984), organization structure can be thought of as comprehending the parameters, which define the way an organization is assembled. It is through an organization's structure that a framework for integrating the organization's strategic plans for the allocation of its resources is achieved. Dalton et al., (1980) consider organization structure as the anatomy of the organization, providing a foundation within which the organization functions and affect the behavior of organization members. Perrow (1967) refers to structure as follows, "In the course of changing material in an organizational setting, the individual must interact with others. The form of interaction is called structure and involves 
arrangements or relationships that permit coordination and control of work". The dimensions of organizational structure were Formalization, Centralization and Complexity. Formalization refers to the extent to which jobs within the organization are standardized in terms of written rules, procedures, and instructions. Standardization is closely in alignment to formalization whereby standardization prescribes or limits behavior and procedures of members of the organization.

Centralization refers to the concentration of decision-making power in the organization. The locus of decision-making can be assessed along two dimensions: level and dispersion (Dev 1989). According to Ouchi and Harris (1976) decision making power could be located higher or lower in the hierarchy and it could be concentrated or dispersed. Centralization sometimes referred to as it is opposite delegation refers to the distribution of decision-making power in the organization (Miller and Drodge 1986). The degree of centralization in an organization may be defined either as the degree of participation in decision-making or the degree of reliance on the hierarchy of authority (Hage and Aiken 1967). Complexity includes the idea of levels, which is referring to the degree of vertical, horizontal, spatial or personal differentiation. Hage (1965) noted that the complexity, or specialization, in an organization is measured by the number of occupational specialties which includes the length of training required. The greater the number of occupations and the longer the period of training required, the more complex the organization. According to Hall et al., (1967) the definition of complexity is the degree of internal segmentation the number of separate parts of the organization as reflected by the division of labor, number of hierarchical levels, and the spatial dispersion of the organization.

\section{RESEARCH METHODOLOGY}

\subsection{Sample and Data Collection}

This case study design selected to determine the extent of relationship between industry structure and organization structure of the low scale hotel organizations. A quantitative research design is selected in order to: (i) examine the factors comprising the industry structure, (ii) investigate the 3-star hotel group level of industry attractiveness, (iii) find out the factors that determined organizational structure, (iv) determine the 3-star hotels organizational structure inclination, and (v) determine the extent of association between the 3 star hotels level of industry attractiveness and the organizational structure.

A Cross-Sectional design is employed where the primary data is collected during a sixweek period extending from July to August. It was important that data is collected within a short span of time as the factors that determine the industry structure might change due to the rate of change in the economic sector.

The number of hotels solicited for participation totalled 110. The hotels included were those that have participated in previous similar studies. The list of hotel organizations was originally derived from several sources such as the hotel directory compiled by Tourism Malaysia and from the Hotel and Restaurant Purchasing Guidebook.

The primary data which were collected via mail survey. It was requested that the questionnaire should be responded by the CEO or any member of the top management team. The primary data collected was intended to gather information on the hotels' top management opinion on how they perceived the current state of the industry environment as they relate to the respect to the intensity of rivalry, the ease of new entrants, the bargaining power of customers and suppliers, and the level of government support. This was to ensure the reliability of the responses since the items asked to relate mainly to information that only to the top management team members would have. The first round of survey questionnaires was mailed in the third month of the research project, and a follow-up was done in the following 
two months. Secondary data were collected from published past research studies, unpublished research project reports, publications by Tourism Malaysia, from articles in academic journals. They were collected throughout the study period.

\subsection{Instrumentation and Scale}

Two instruments were required for the study. These instruments consisted of structured questions aimed at identifying:

\section{A. Industry Structure}

Intensity of Rivalry:

- Availability of excess capacity.

- Investors and lenders are cautious.

- Considerable costs required for renovation/building.

- Flexibility of conversion the building for other business/purpose.

- Difficulty in establishing products/services differentiation.

- Intensity of stealing market shares.

Threats of new entrants:

- Requirement of high capital to start the hotel business.

- Operating cost advantage of large hotels.

- Difficulty in establishing distribution channel for new hotels.

- Government incentives/policies that are attractive for new entrants, existing hotel rooms and services are highly differentiated.

- Customers' loyalty is high.

- Existing hotels will react aggressively to new entrants.

Customers' Bargaining Power:

- Customers are highly concentrated geographically.

- A major portion of the hotel sales is derived from a few customers groups the hotel products/services are highly perishable.

- Major customers can switch to other hotels but with high cost implications, major customers can dictate terms of sales.

Suppliers bargaining power:

- Ample availability of hotel rooms.

- Labour can be substituted easily.

- Local material suppliers are easily available.

- A wide selection of material suppliers is available.

- It is easy to switch material suppliers.

Level of Threats of Substitute Products/Services:

- Customers have lodging alternatives.

- Impact of teleconferencing, e-mail services, and other communication innovations have shortened the length of stay.

- Flights regularity to regional destinations have impacted room sales.

- Timesharing, cruise lines and apartments have impacted room sales. 
- Customers not on expense account seeking hotels with lower rates.

- Customers not on expense account will shortened their length of stay.

Level of Government Support:

- Level of state government interest in the industry's development.

- Amount of incentives given by the government for the industry's growth.

- Extent in which the government represents the major customer.

- Extent to which the government was the major supplier.

- Extent of rules and regulations pertaining to hotel operations.

\section{Scale}

A 6-point Likert-like scale is used to measure the perception on this variable. The following characteristics were indicated for the range of the responses:

Table 1

\begin{tabular}{|c|c|c|c|c|c|}
\hline $\begin{array}{c}\text { Very } \\
\text { Weak }\end{array}$ & $\begin{array}{c}\text { Relatively } \\
\text { Weak }\end{array}$ & $\begin{array}{c}\text { Slightly } \\
\text { Weak }\end{array}$ & $\begin{array}{c}\text { Slightly } \\
\text { Strong }\end{array}$ & $\begin{array}{c}\text { Relatively } \\
\text { Strong }\end{array}$ & $\begin{array}{c}\text { Very } \\
\text { Strong }\end{array}$ \\
\hline $\begin{array}{c}\text { Very } \\
\text { Attractive }\end{array}$ & $\begin{array}{c}\text { Relatively } \\
\text { Attractive }\end{array}$ & $\begin{array}{c}\text { Slightly } \\
\text { Attractive }\end{array}$ & $\begin{array}{c}\text { Slightly } \\
\text { Unattractive }\end{array}$ & $\begin{array}{c}\text { Relatively } \\
\text { Unattractive }\end{array}$ & $\begin{array}{c}\text { Very } \\
\text { Unattractive }\end{array}$ \\
\hline $1.00-1.83$ & $1.84-2.66$ & $2.67-3.49$ & $3.50-4.32$ & $4.33-5.15$ & $5.16-6.00$ \\
\hline
\end{tabular}

\section{B. Organization Structure}

Formalization

- Use of written procedures.

- Extensiveness of existence of written policies, rules, and regulations.

- Decisions guided by mission/vision.

- Performance measures are quantitative.

- Employees are organized in work teams.

Centralization

- Frequency of participation in recruitment decisions.

- Decision making guided by standard operating procedures.

- Major strategic decisions made by CEO.

- Frequency of participation in promotional decisions.

- Degree to which line of authority is defined.

- Major units are served by a centralized staff of experts.

- Organizational structure is hierarchical.

- Employees allowed discretions in decision making.

- Formal information is funnel vertically down.

Complexity

- Employees' influence on strategic decisions.

- Operational tasks are standardized.

- Job/Tasks are clearly defined.

- Major units departmentalized by functions. 


\section{Scale}

Table 2

\begin{tabular}{|c|c|c|c|c|c|}
\hline Open & $\begin{array}{c}\text { Relatively } \\
\text { Open }\end{array}$ & $\begin{array}{c}\text { Slightly } \\
\text { Open }\end{array}$ & $\begin{array}{c}\text { Slightly } \\
\text { Closed }\end{array}$ & $\begin{array}{c}\text { Relatively } \\
\text { Closed }\end{array}$ & Close \\
\hline Informal & $\begin{array}{c}\text { Relatively } \\
\text { Informal }\end{array}$ & $\begin{array}{c}\text { Slightly } \\
\text { Informal }\end{array}$ & Slightly Formal & $\begin{array}{c}\text { Relatively } \\
\text { Formal }\end{array}$ & Formal \\
\hline Decentralized & $\begin{array}{c}\text { Relatively } \\
\text { Decentralized }\end{array}$ & $\begin{array}{c}\text { Slightly } \\
\text { Decentralized. }\end{array}$ & $\begin{array}{c}\text { Slightly } \\
\text { Centralized }\end{array}$ & $\begin{array}{c}\text { Relatively } \\
\text { Centralized. }\end{array}$ & Centralized \\
\hline+ Complex & $\begin{array}{c}\text { Relatively } \\
\text { Complex }\end{array}$ & $\begin{array}{c}\text { Slightly } \\
\text { Complex }\end{array}$ & $\begin{array}{c}\text { Slightly } \\
\text { Standardized }\end{array}$ & $\begin{array}{c}\text { Relatively } \\
\text { Standardized }\end{array}$ & Standardized \\
\hline $1.00-1.83$ & $1.84-2.66$ & $2.67-3.49$ & $3.50-4.32$ & $4.33-5.15$ & $5.16-6.00$ \\
\hline
\end{tabular}

\section{FINDINGS}

\subsection{Response Rate and Respondent Profile}

The number of hotels solicited for participation was 110 hotels. A total of 223 -star hotels responded for participation and this represented 20 percent respond rate. Of the 22 responding hotels, the responses were derived from 12 (55\%) who were general managers, $2(9 \%)$ were directors, $7(32 \%)$ were heads of marketing, and another 1 was the assistant human resource department head.

\subsection{Industry Structure}

The level of attractiveness of the Industry Structure is measured on 6 variables: (1) Intensity of rivalry, (2) Threat of new entrants, (3) Bargaining power of customer, (4) Bargaining power of suppliers, (5) Threat of substitutes, and (6) Level of government support.

\subsubsection{Intensity of Rivalry}

The intensity of rivalry is measured on 6 factors which were: (i) the degree to which capacity is excess, (ii) the extent of cautiousness of lenders and investors, (iii) the cost for renovations / building, (iv) the flexibility of building for conversion, (v) the level of difficulty in differentiating product/ service, and (vi) the intensity of stealing market shares.

The 3-star hotel group experienced a slightly strong intensity of rivalry level, as indicated in Table 3. This was supported in the slightly high amount of excess capacity indicating that the room occupancy rate was slightly low, and the slightly strong inability to differentiate their products or services level. However, the lenders and investors were more cautious in extending loans to this group of hotels and the hotels indicated that the cost of renovations were somewhat high. Related to this, they also stated that their excess hotel space was less able to be converted for some other revenue generating source.

Table 3 Intensity of Rivalry

\begin{tabular}{|c|l|c|l|}
\hline No & \multicolumn{1}{|c|}{ Factors } & Mean & \multicolumn{1}{c|}{ Meaning } \\
\hline 1 & Excess capacity & 3.93 & Slightly Strong \\
\hline 2 & Cautious lenders and investors & 4.51 & Relatively Strong \\
\hline 3 & High cost for renovations / building & 4.43 & Relatively Strong \\
\hline 4 & Building flexibility for conversion & 3.40 & Slightly Weak \\
\hline 5 & Difficulty in Product/ service differentiation & 3.79 & Slightly Strong \\
\hline 6 & Intensity of stealing market shares & 4.23 & Slightly Strong \\
\hline & Overall & $\mathbf{4 . 0 5}$ & Slightly Strong \\
\hline
\end{tabular}




\subsubsection{Level of Threats of New Entrants}

The composite mean score for the threats of new entrants was derived from combining the mean scores of 7 dimensions. The dimensions were the: (1) requirement of high capital to start the hotel business, (2) operating cost advantage of large hotels, (3) difficulty in establishing distribution channel for new hotels, (4) government incentives/policies that are attractive for new entrants, (5) existing hotel rooms and services are highly differentiated, (6) customers' loyalty is high, and (7) existing hotels will react aggressively to new entrants.

In the 3-star hotel category, the overall threats of new entrants were found to be slightly strong, as shown in Table 4. A relatively strong support was indicated in the relatively high capital to start the 3-star hotel business. The following six factors indicated similar results to the overall findings, that the larger hotels did had a slight advantage in operating costs, that new hotels would find that it would be somewhat difficult to establish distribution channels, that the government did provide some attractive incentives and policies to support new entrants, that the hotel services could be differentiated, that customer loyalty was somewhat strong, and that the hotels were quite aggressive to new entrants.

Table 4 Threats of New Entrants

\begin{tabular}{|c|c|c|c|}
\hline No & Factors & Mean & Meaning \\
\hline 1 & High capital to start business & 4.61 & Relatively Strong \\
\hline 2 & Large hotels have operating cost advantage & 4.25 & Slightly Strong \\
\hline 3 & $\begin{array}{l}\text { Difficulty in establishing distribution channels for } \\
\text { new hotels }\end{array}$ & 4.16 & Slightly Strong \\
\hline 4 & $\begin{array}{l}\text { Government incentives/ policies are attractive for } \\
\text { new entrants }\end{array}$ & 3.79 & Slightly Strong \\
\hline 5 & Hotel services are highly differentiated & 4.04 & Slightly Strong \\
\hline 6 & High Customer loyalty & 4.12 & Slightly Strong \\
\hline 7 & Hotels aggressive to new entrants & 3.83 & Slightly Strong \\
\hline & Overall & 4.11 & Slightly Strong \\
\hline
\end{tabular}

\subsubsection{Bargaining Power of Customers}

The strength of customers' bargaining power was cumulatively measured by averaging the mean scores of five dimensions. The dimensions were: (1) customers are highly concentrated geographically, (2) a major portion of the hotel sales is derived from a few customers groups, (3) the hotel products/services are highly perishable, (4) major customers can switch to other hotels but with high cost implications, and (5) major customers can dictate terms of sales.

For the 3-star hotel group, as was indicated in Table 5, the bargaining power of customers was slightly strong. Besides indicating that the hotel rooms were somewhat unperishable, the other factors were in support of the overall findings in that the customers were somewhat geographically concentrated, that a few customers' group could influenced the amount of sales, that major customers could somewhat dictate the sales terms, and that they could easily switch their accounts to other providers if they were unhappy with the present arrangement.

Table 5 Bargaining Power of Customers

\begin{tabular}{|c|l|c|c|}
\hline No & Factors & Mean & Meaning \\
\hline 1 & Customers concentrated geographically & 4.14 & Slightly Strong \\
\hline 2 & A few customer group determine sales & 4.23 & Slightly Strong \\
\hline 3 & Product/Services highly perishable & 3.43 & Slightly Weak \\
\hline 4 & Major customers can easily switch hotels & 3.74 & Slightly Strong \\
\hline 5 & Major customers can dictate sales terms & 4.18 & Slightly Strong \\
\hline & Overall & $\mathbf{3 . 9 4}$ & Slightly Strong \\
\hline
\end{tabular}




\subsubsection{Bargaining Power of Suppliers}

The bargaining power of suppliers referred specifically to labours and material suppliers for the hotel groups. The suppliers bargaining power was measured on 5 factors which were: (1) ample availability of hotel rooms, (2) labour can be substituted easily, (3) local material suppliers are easily available, (4) a wide selection of material suppliers are available, and (5) it is easy to switch material suppliers.

The 3-star hotel category indicated that the overall bargaining power of suppliers was slightly strong, as indicated in Table 6 . This finding was supported by the somewhat strong availability of local material suppliers, and that it was relatively easy to change material suppliers. However, the labour supply was in short supply and that labour cannot be substituted for example with the use of technology.

Table 6 Bargaining Power of Suppliers

\begin{tabular}{|l|l|l|l|}
\hline NO & \multicolumn{1}{|c|}{ Factors } & \multicolumn{1}{c|}{ Mean } & \multicolumn{1}{c|}{ Meaning } \\
\hline 1 & Ample labour supply & 3.47 & Slightly Weak \\
\hline 2 & Labor can be substituted & 3.07 & Slightly Weak \\
\hline 3 & Local material suppliers available & 3.89 & Slightly Strong \\
\hline 4 & Material suppliers available & 3.79 & Slightly Strong \\
\hline 5 & Easy to switch material suppliers & 4.17 & Slightly Strong \\
\hline & Overall & 3.68 & Slightly Strong \\
\hline
\end{tabular}

\subsubsection{Level of Threats of Substitute Products and Services}

The level of threats of substitute products/services is determined by combining the mean scores of the following 6 dimensions. They referred to the extent in which: (1) customers have lodging alternatives, (2) the impact of teleconferencing, e-mail services, and other communication innovations have shortened the length of stay, (3) flights regularity to regional destinations have impacted room sales, (4) timesharing, cruise lines and apartments have impacted room sales, (5) customers not on expense account seeking hotels with lower rates, and (6) customers not on expense account will shortened their length of stay.

The overall level of threats of substitute products and services for the 3-star hotel group was slightly strong. With the exception of the ample availability of lodging alternatives, all the other 5 factors indicated findings in support of the overall findings in that the availability of communication innovations had somewhat shortened the length of stay, the more regularity of flights availability and increase in timesharing, and cruise lines and had an impact on their room sales, that customers that did not have expense account would seek hotels with lower rates or they might shortened their length of stay instead.

Table 7 Level of Threats of Substitute Products/Services

\begin{tabular}{|c|l|l|l|}
\hline No & \multicolumn{1}{|c|}{ Factors } & \multicolumn{1}{|c|}{ Mean } & \multicolumn{1}{|c|}{ Meaning } \\
\hline 1 & Lodging alternatives available & 4.48 & Relatively Strong \\
\hline 2 & Communication innovations -shortened length of stay & 4.19 & Slightly Strong \\
\hline 3 & Flights regularity - impact on room sales & 3.76 & Slightly Strong \\
\hline 4 & $\begin{array}{l}\text { Timesharing, cruise lines and time-sharing } \\
\text { apartments - impact on room sales }\end{array}$ & 3.67 & Slightly Strong \\
\hline 5 & $\begin{array}{l}\text { Customers not on expense account will seek lower } \\
\text { rates hotel }\end{array}$ & 4.28 & Slightly Strong \\
\hline 6 & $\begin{array}{l}\text { Customers not on expense account - shortened length } \\
\text { of stay }\end{array}$ & $4.2 \mathrm{O}$ & Slightly Strong \\
\hline & Overall & 4.10 & Slightly Strong \\
\hline
\end{tabular}




\subsubsection{Level of Government Support}

The level of government support is tapped on five dimensions. These dimensions were: (1) the level of state government interest in the industry's development, (2) the amount of incentives given by the government for the industry's growth, (3) the extent in which the government represents the major customer, (4) the extent to which the government was the major supplier, (5) the extent of rules and regulations pertaining to hotel operations.

The 3-star hotel group, as shown in Table 8, expressed that the level of government support was slightly strong. This finding was supported in 4 of the 5 factors which were the somewhat strong level of government interest in the industry's development, that it had also provided quite a strong incentives for its growth, that the government remained a major customer, but it also had provided a lot of rules and regulations pertaining to the hotels' operation. The only slightly weak part was the government role as a major supplier.

Table 8 Level of Government Support

\begin{tabular}{|c|l|c|l|}
\hline No & \multicolumn{1}{|c|}{ Factors } & Mean & \multicolumn{1}{|c|}{ Meaning } \\
\hline 1 & $\begin{array}{l}\text { Government interest in industry's } \\
\text { developments }\end{array}$ & 3.58 & Slightly Strong \\
\hline 2 & $\begin{array}{l}\text { Government incentives contributed } \\
\text { industry growth }\end{array}$ & 3.60 & Slightly Strong \\
\hline 3 & Government is major customer & 3.68 & Slightly Strong \\
\hline 4 & Government is my major supplier & 2.70 & Slightly Weak \\
\hline 5 & $\begin{array}{l}\text { A lot of rules/ regulations pertaining to } \\
\text { hotel operations }\end{array}$ & 4.23 & Slightly Strong \\
\hline & OVERALL & 3.56 & Slightly Strong \\
\hline
\end{tabular}

\subsubsection{Overall Industry Structure}

The overall findings indicated the level of industry attractiveness by combining the 6 factors of: the intensity of rivalry, the threat of new entrants, the bargaining power of customer, the bargaining power of suppliers, the threat of substitutes, and the level of government support. As indicated in Table 9, the level of industry attractiveness of the 3-star hotel group was slightly unattractive. This was supported by the somewhat strong findings on all the 6 factors as indicated above.

Table 9 Level of Industry Attractiveness

\begin{tabular}{|c|l|c|l|}
\hline No & \multicolumn{1}{|c|}{ Factors } & Mean & \multicolumn{1}{|c|}{ Meaning } \\
\hline 1 & Intensity of rivalry & 4.05 & Slightly Strong \\
\hline 2 & Threat of new entrants & 4.14 & Slightly Strong \\
\hline 3 & Bargaining power of customer & 3.70 & Slightly Strong \\
\hline 4 & Bargaining power of suppliers & 3.69 & Slightly Strong \\
\hline 5 & Threat of substitutes & 3.56 & Slightly Strong \\
\hline 6 & Level of government support & 4.10 & Slightly Strong \\
\hline & $\begin{array}{l}\text { Overall } \\
\text { Level of attractiveness }\end{array}$ & 3.87 & $\begin{array}{l}\text { Slightly } \\
\text { Unattractive }\end{array}$ \\
\hline
\end{tabular}

\subsection{Organization Structure Variable}

Organization Structure is measured on 3 variables: (i) Formalization, (ii) Centralization, and (iii) Complexity. 


\subsubsection{Formalization Variable}

Formalization variables was gauged based on 5 factors and they were: the use of written procedures, the extensiveness of existence of written policies, rules and regulations, that the decisions guided by mission/vision, the performance measures are quantitative, and the employees are organized in work teams

Table 10 showed the factors that determined the overall level of formalization in the 3 -star hotel group. The result indicated that the 3 -star hotel group was slightly formal, and this was reflected in the employees that they were sometimes organized in work teams. Stronger support was found in the usual use of written procedures, in the extensive availability of written policies, rules and regulations, and the use of quantitative performance measures. However, the decisions were rarely guided by the hotel's mission or vision statements.

Table 10 Formalization Variables

\begin{tabular}{|c|l|c|l|}
\hline No & \multicolumn{1}{|c|}{ FACTORS } & MEAN & \multicolumn{1}{|c|}{ Meaning } \\
\hline 1 & Use of written procedures & 4.76 & $\begin{array}{l}\text { Relatively Formal } \\
\text {-usually }\end{array}$ \\
\hline 2 & $\begin{array}{l}\text { Extensiveness of existence of written } \\
\text { policies, rules and regulations }\end{array}$ & 5.05 & $\begin{array}{l}\text { Relatively Formal } \\
\text {-to a very large extent }\end{array}$ \\
\hline 3 & Decisions guided by mission/vision & 2.29 & $\begin{array}{l}\text { Relatively Informal } \\
\text {-rarely }\end{array}$ \\
\hline 4 & Performance measures are quantitative & 4.57 & $\begin{array}{l}\text { Relatively Formal } \\
\text {-mostly }\end{array}$ \\
\hline 5 & Employees are organized in work teams & 3.76 & $\begin{array}{l}\text { Slightly Formal } \\
\text {-sometimes }\end{array}$ \\
\hline & OVERALL & 4.09 & Slightly Formal \\
\hline
\end{tabular}

\subsubsection{Centralization Variable}

Centralization variable is measured on the following 9 factors which were: the frequency of participation in recruitment decisions, the decision making guided by standard operating procedures, the major strategic decisions made by $\mathrm{CEO}$, the frequency of participation in promotional decisions, the degree to which line of authority is defined, the major units are served by a centralized staff of experts, the organizational structure is hierarchical, the employees were allowed discretions in decision making, and that the formal information is funnel vertically down.

Table 11 indicated that the 3-star hotel group indicated that their organization structure was slightly centralized. The findings on the factors were mixed between relatively decentralized and relatively centralized. However, 5 factors were indicated that they were relatively centralized, and they were the frequency of participation in recruitment decisions, the decision making that were guided by standard operating procedures, the frequency of participation in promotional decisions, the degree to which line of authority is defined, and the major units were served by a centralized staff of experts. Two factors indicated their support for a slightly decentralized structure and they were that the employees were allowed discretions in decision making, and that the formal information was funnel vertically down, but factor was relatively strong on support for a decentralized which was on the hierarchical organizational structure, and the strongest support for decentralization was the major strategic decisions made only by chief executive officer. 
Table 11 Centralization Variables

\begin{tabular}{|c|c|c|c|}
\hline No. & Factors & Mean & Meaning \\
\hline 1 & $\begin{array}{l}\text { Frequency of participation in recruitment } \\
\text { decisions }\end{array}$ & 4.71 & $\begin{array}{l}\text { Relatively Centralized } \\
\text {-to some extent }\end{array}$ \\
\hline 2 & $\begin{array}{l}\text { Decision making guided by standard operating } \\
\text { procedures }\end{array}$ & 4.71 & $\begin{array}{l}\text { Relatively Centralized } \\
\text {-to some extent }\end{array}$ \\
\hline 3 & Major strategic decisions made by CEO & 1.62 & $\begin{array}{l}\text { Decentralized } \\
\text {-very seldom }\end{array}$ \\
\hline 4 & $\begin{array}{l}\text { Frequency of participation in promotional } \\
\text { decisions }\end{array}$ & 5.10 & $\begin{array}{l}\text { Relatively Centralized } \\
\text {-most of the time }\end{array}$ \\
\hline 5 & Degree to which line of authority is defined & 5.05 & $\begin{array}{l}\text { Relatively Centralized } \\
\text {-to a large extent }\end{array}$ \\
\hline 6 & $\begin{array}{l}\text { Major units are served by a centralized staff of } \\
\text { experts }\end{array}$ & 4.62 & $\begin{array}{l}\text { Relatively Centralized } \\
\text {-to some extent }\end{array}$ \\
\hline 7 & Organizational structure is hierarchical & 2.43 & $\begin{array}{l}\text { Relatively Decentralized } \\
\text {-to a minor extent }\end{array}$ \\
\hline 8 & $\begin{array}{l}\text { Employees allowed discretions in decision } \\
\text { making }\end{array}$ & 2.95 & $\begin{array}{l}\text { Slightly Decentralized } \\
\text {-to a limited extent }\end{array}$ \\
\hline 9 & Formal information is funnel vertically down & 2.71 & $\begin{array}{l}\text { Slightly Decentralized } \\
\text {-to a limited extent }\end{array}$ \\
\hline & OVERALL & 3.77 & Slightly Centralized \\
\hline
\end{tabular}

\subsubsection{Complexity Variable}

Complexity is measured based on the combination of the following 4 factors: employees' influence on strategic decisions, operational tasks are standardized, job/tasks are clearly defined, and major units were departmentalized by functions.

As indicated in Table 12, the 3-star hotel groups were relatively complex. Two factors indicated similar findings to the overall results, and they were that the job/tasks were clearly defined, and that major units were departmentalized by functions. Two factors indicated a slight support for complexity, and they were that employees could influence on strategic decisions, and that operational tasks were standardized.

Table 12 Complexity Variables

\begin{tabular}{|c|l|c|l|}
\hline No. & \multicolumn{1}{|c|}{ Factors } & Mean & \multicolumn{1}{|c|}{ Meaning } \\
\hline 1 & $\begin{array}{l}\text { Employees' influence on strategic } \\
\text { decisions }\end{array}$ & 3.27 & $\begin{array}{l}\text { Slightly Complex } \\
\text {-somewhat }\end{array}$ \\
\hline 2 & Operational tasks are standardized & 2.95 & $\begin{array}{l}\text { Slightly Complex } \\
\text {-to some extent }\end{array}$ \\
\hline 3 & Job/Tasks are clearly defined & 1.95 & $\begin{array}{l}\text { Relatively Complex } \\
\text {-to a large extent }\end{array}$ \\
\hline 4 & $\begin{array}{l}\text { Major units departmentalized by } \\
\text { functions }\end{array}$ & 2.00 & $\begin{array}{l}\text { Relatively Complex } \\
\text {-to a large extent }\end{array}$ \\
\hline & OVERALL & 2.54 & Relatively Complex \\
\hline
\end{tabular}

\subsubsection{Overall Organization Structure}

The overall organization structure was determined by the combination of the three variables: Formalization, Centralization, and Complexity. As indicated in Table 13, overall, the 3-star hotel group organizational structure was considered as slightly closed. This was supported by slightly formal, slightly centralized, and relatively complex characteristics of the organization structure. 
Table 13 Hotel Organizational Structure

\begin{tabular}{|c|c|c|c|}
\hline Formalization & Centralization & Complexity & Overall \\
\hline Sightly & Slightly Centralized & Relatively & Slightly Closed \\
Formal & 3.77 & Complex & 3.47 \\
4.09 & & 2.54 & \\
\hline
\end{tabular}

\subsection{Extent of Association between Industry Structure and Organization Structure}

The extent of association between Industry Structure and Organization Structure is as indicated in Table 14 which showed a Full Association. Industry Structure was found to be Slightly Unattractive while the Hotel Organization Structure was Slightly Closed. The variance between the two variables was very small at $6.67 \%$. The proposition stated that when the hotel industry is unattractive, the 3-star hotel group would adopt a closed organizational structure, thus there was a Full Support for the proposition.

(Note: A Full support for the proposition if the variance was $10 \%$ or less)

Table 14 Extent of Association between Industry Structure and Organization Structure

\begin{tabular}{|l|l|c|c|}
\hline \multicolumn{1}{|c|}{ Variables } & \multicolumn{1}{|c|}{ Findings } & \multicolumn{1}{|c|}{ Variance } & $\begin{array}{c}\text { Extent of } \\
\text { Relationship }\end{array}$ \\
\cline { 1 - 2 } Industry Structure & Slightly Unattractive & \multirow{2}{*}{0.40} & \multicolumn{1}{|c|}{ Full } \\
& 3.87 & $6.67 \%$ & Association \\
\hline Hotel Organization & Slightly Closed & & \\
Structure & 3.47 & \\
\hline
\end{tabular}

\section{SUMMARY AND CONCLUSION}

The purpose of the research were to examine the factors comprising the industry structure, to investigate the 3-star hotel group level of industry attractiveness, to find out the factors that determined organizational structure, to determine the 3-star hotels organizational structure inclination, and to determine the extent of association between the 3-star hotels level of industry attractiveness and the organizational structure. To those ends, the study was able to determine the extent of industry attractiveness through the identification of the variables and factors contributing towards the industry attractiveness and the extent of organization structure. All the seven variables that in combination, determined the extent of industry attractiveness were indicated as slightly strong, thus contributing to unattractiveness of the industry. Likewise, the overall organization structure was indicated as slightly closed. Thus, the findings fully supported the proposition of the study which assumed that where the hotel industry is unattractive, the hotel organizations would adopt a closed organizational structure.

\section{REFERENCES}

[1] Dalton, D.R, Todor, W.D., Spendolini, M.J., Fielding, G.J., and Porter, L.W. (1980). Organization Structure and Performance: A Critical Review. The Academy of Management Review, 5(1), 49-64.

[2] Dev, C.S. (1988). Environmental uncertainty, business strategy and financial performance: A study of the lodging industry. Unpublished Doctoral Dissertation, Virginia Polytechnic Institute and State University, Blacksburg, VA.

[3] Hage, J. (1965). An axiomatic theory of organizations. Administrative Science Quarterly, 10, 289-320. 
[4] Hage, Jerald, and Michael Aiken. 1967. Relationship of centralization to other structural properties. Administrative Science Quarterly, 12 (1), 72-93.

[5] Hall, R.H., J.E. Haas and N.J. Johnson. (1967). Organizational size, complexity and formalization. American Sociological Review, 32, 903-12.

[6] Miller, D., and Droge, C. (1986). Psychological and traditional determinants of structure. Administrative Science Quarterly. 31(4), 539-560.

[7] Ouchi, W. G., and Harris, R. T. 1976. Structure, technology and environment. In G. Strauss, R. E. Miles, C. C. Snow, A. S. Tannebaum (Eds.), Organizational behavior: Research and issues: 107-140. Belmont, CA: Wadsworth Publishing.

[8] Perrow, C. (1967). A framework for the comparative analysis of organizations. American Sociological Review, 32 (2), 194-208.

[9] Porter, M. E. (1980). Competitive Strategy: Techniques for Analyzing Industries and Competitors. New York, NY: Free Press.

[10] Schaffer, J.D. (1984). Strategy, Organization Structure and Success in the Lodging Industry. International Journal of Hospitality Management, 3(4). 